Studia nad Rodziną

UKSW

2015 R. XIX nr 2 (37)

\title{
Geniusz bł. Jana Pawła II, red. ks. Przemysław Artemiuk i ks. Jarosław Kotowski, Lomża 2011, 214 s.
}

Postać papieża Jana Pawła II od wielu już lat, właściwie od początku jego pontyfikatu, jest przedmiotem licznych publikacji, zarówno naukowych, jak i popularnonaukowych. Szczególną popularnością i zainteresowaniem cieszą się albumy i inne pozycje dokumentujące jego pielgrzymki apostolskie i zawierające treść jegø przemówień, wszystko opatrzone oczywiście pięknymi fotografiami, a nierzadko też kasetami, płytami i filmami. W ostatnich latach, to znaczy od momentu śmierci wielkiego papieża i w czasie trwania gorącej modlitwy do Boga o jego rychłą beatyfikację, przypominano jego osobę i bogate nauczanie. Wydano wiele książek z tekstami dokumentów, katechez i przemówień papieskich. Przypominanie i analizę tych tekstów traktowano i traktuje się nadal jako swoistą formę realizacji testamentu Jana Pawła II i obietnic złożonych w dniach między jego śmiercią a pogrzebem, kiedy - jak mówiono - świat się zatrzymał. Wciąż dostrzega się jednak, że testament ten nie jest w wystarczającym stopniu realizowany i że wiele osób przyznających się do wiary w Chrystusa i przynależących do Kościoła katolickiego oraz deklarujących swoje przywiązanie i podziw dla Jana Pawła II nie zna jego nauczania. Publikowano też świadectwa różnych osób, które opowiadały o wielkim papieżu i o swoich doświadczeniach i przeżyciach, które towarzyszyły spotkaniom z tym niezwykłym człowiekiem. Wystarczy wspomnieć tu chociażby wydane niedawno świadectwo kard. Stanisława Dziwisza.

Redagowana przez ks. Przemysława Artemiuka i ks. Jarosława Kotowskiego publikacja wpisuje się w ten nurt ukazywania Jana Pawła II jako niezwykłego i nietuzinkowego człowieka. Już sam tytuł książki wskazuje na to, że będzie chodziło o genialną postać, nad którą należy się pochylić i dłużej zatrzymać, aby docenić jej dokonania i przybliżyć szerszej społeczności wyjątkowe, ponadczasowe znaczenie wielkości i niezwykłości tego człowieka.

Omawiana pozycja, która stanowi kolejny tom łomżyńskiej serii wydawniczej „Lumen Fidei”, podejmującej fundamentalne zagadnienia wiary w perspektywie katechetycznej, jest pokłosiem sesji popularno-naukowej pt. „Geniusz bł. Jana Pawła II - teologa, poety i wychowawcy”, która odbyła się 3 czerwca 2011 roku w Zespole Szkół nr 5 im. Unii Europejskiej w Ostrołęce. Książka zawiera teksty wygłoszone podczas sesji i dołączone później. 
Publikacja obejmuje wstęp redaktorów tomu, słowo bpa Tadeusza Bronakowskiego, jedenaście artykułów i noty o autorach. Ks. Przemysław Artemiuk w pierwszym artykule prezentuje oblicza bł. Jana Pawła II i ukazuje go jako poetę w relacji do Czesława Miłosza, ks. Jarosław Kotowski jako wychowawcę, ks. Marek Skierkowski jako twórcę nowej Europy, ks. Paweł Tarasiewicz jako rzecznika humanizmu, a ks. Grzegorz Malinowski jako filozofa. Ewa Gralewska podejmuje próbę interpretacji sztuki Karola Wojtyły „Przed sklepem jubilera”. Mariola AndrychowskaKozłowska przedstawia postawę i działania Jana Pawła II wobec totalitaryzmu. Ks. Dariusz Tułowiecki z socjologicznego punktu widzenia próbuje odpowiedzieć na pytanie: Czy nauczanie Jana Pawła II traktowane jest jako dziedzictwo czy balast? Ks. Marek Kumór w świetle encykliki Jan Pawła II Evangelium vitae snuje refleksje na temat prawa do godnej śmierci, a ks. Adam Kumorek kreśli obraz kapłaństwa, jaki wyłania się z listów Jana Pawła II na Wielki Czwartek.

Na uwagę zasługuje naświetlenie stosunkowo mało znanych, omawianych czy zauważanych aspektów $z$ biografii wielkiego papieża, takich jak jego bycie poetą czy wychowawcą. Często przypominano np. jego ogromny wkład w zmianę oblicza Kościoła i urzędu papieża oraz postrzegania go przez ludzi wierzących i niewierzących. Wysoko oceniano również zaangażowanie Jana Pawła II w obronę praw i godności człowieka, jego starania o zachowanie pokoju na świecie czy niepowtarzalną rolę w obaleniu komunizmu. Publikacja redagowana przez ks. Artemiuka i ks. Kotowskiego ukazuje Błogosławionego jako ezłowieka, który byłteologiem, poeta $\mathrm{i}$ wychowawca. Jest to na pewno cenny wkład w kreślenie całościowego obrazu tego wielkiego, genialnego człowieka.

Autorzy artykułów zamieszczonych w omawianej publikacji mieli na celu zaprezentowanie błogosławionego Jana Pawła II jako teologa, poety i wychowawcy. Cel ten z pewnością osiągnęli. Wskazali również na papieża jako filozofa i humanistę. Na uwagę zasługuje przejrzysty i dostępny język wyrażania podejmowanych i omawianych zagadnień. Szkoda tylko, że kolejność zamieszczonych w książce artykułów nie segreguje wyraźnie i nie wyodrębnia omawianych aspektów. Niemniej jednak to wartościowa pozycja, przydatna do lepszego poznania osoby Jana Pawła II i jego nauczania. Należy polecić tę publikację nie tylko tym, którzy pragną coraz głębiej poznawać fenomen i geniusz Papieża-Polaka, lecz również wszystkim, którzy interesują się jego teologią i twórczością poetycką, a także podejmującym trudne zadanie wychowania. Bł. Jan Paweł II w perspektywie prezentowanego opracowania to geniusz, ale przede wszystkim człowiek, który także swoim talentem dawał świadectwo wiary i służył Bogu i ludziom. 